Reference: Belot, Céline (2021), "Disentangling Varieties of Nationalism: Why does it matter?”, French Politics, vol.19 n², p.218-249.

\title{
Disentangling varieties of French nationalism, why does it matter?
}

Keywords: nationalism, France, civic vs. ethnic, immigration, solidarity.

\begin{abstract}
National identity claims have taken a growing importance in the French political landscape these last decades. While representations of French national identity has long been scrutinized from an elite perspective, much less is known about "What is it to be French?" from a citizen's perspective. This article aims at filling this gap. Using the European Values Study data, from 1981 to 2018, it first offers a general measure of change in French people national claims during that period. Building on a classification, it then proposes to disentangle five different types of French nationalism. Finally, the article test the explanatory power of these types of nationalism on support for attitudes and a few policy preferences which involve representations of the ingroup and the outgroup such as immigration and solidarity policies.
\end{abstract}




\section{Introduction}

Over the last few decades, discourse on national identity has overwhelmed the French political landscape. From the first electoral successes of the Front National in the 1980s onwards, "national identity" became an issue which needed to be dealt with by political leaders. A number of political decisions followed, from the reform of the conditions to gain French nationality in 1993, to the creation of the "Ministry of Immigration, Integration, National Identity and Solidarity Development" in 2007 by president Sarkozy and the launch of a "great debate on immigration" two years later and to successive immigration laws (five in the last fifteen years) defining, among other decisions, who might obtain French nationality.

Dutiful observers of the French 2017 presidential election could not have missed the importance of national identity claims in the discourse of the candidates. From the right of the political spectrum to the left, almost all the candidates made national identity claims. The two main protagonists of these national identity claims were, however, the two candidates who reached the second round of the French presidential election, Emmanuel Macron and Marine Le Pen. Both reaffirmed the importance of national pride. When Macron stated: "I want us to be proud again to be French, thanks to our culture, our international influence and our language" (Macron, 2017), Le Pen answered back: "Don't give up, be proud to be French" (Le Pen, 2017b). As the leader of the Rassemblement National, former Front National, the latter even multiplied such references to French national identity from advocating "teaching love for France in schools" to claiming: "What is at stake: France and its civilisation" (Le Pen, 2017a) and denouncing the determination of Mr Macron "to go further in vandalizing France, our social protection, our national identity" (Le Pen, 2017b).

How do those claims affect social representations of "What is it to be French?" These representations have long been studied through school textbooks (Bozec, 2010), gastronomy 
(Martigny, 2010) and Champagne (Kolleen, 2003). Representations of French national identity are also often scrutinized through the prism of memories, such as memorial topoï (Nora, 1986 ; 2011 ; Pérès, 1989), history museums (Thiesse, 2010) or analyses of political practices of the past (Andrieu et al., 2006). Studying these representations helped to understand how the French nation was built and is permanently reified from a top down perspective (Weil, 2005). What we do not know is "What is it to be French?" from a citizen's perspective. As stated by Duchesne, "the complex feelings citizens have about their nation (...) has been somewhat overlooked. Indeed we might even say this question is a blind spot in the French academic context" (2016, p.483). This article aims at filling this gap. More precisely, using the European Values Study data, from 1981 to 2018, it first offers a general measure of change in French nationalism during that period. It then proposes to disentangle the different configurations of French nationalism and finally to test the explanatory power of these configurations of nationalism on support for attitudes and policies towards both immigration and solidarity. Nationalism indeed appears both as a source of exclusion and inclusion, as a resource to legitimise violence towards the outgroup or to account for solidarity towards the ingroup (Calhoun, 2007). Disentangling varieties of nationalism thus appears particularly crucial when trying to explain support for policies which involve a national ingroup and national outgroups such as immigration policies and solidarity policies.

\section{Lay representations of French national identity: What do we know?}

Since Anderson's influential book, national identities have been acknowledged as “imagined communities" (Anderson, 1983). Studies show that these communities are built from infancy (Barrère \& Martuccelli, 1998; Throssel, 2015). As claimed by Billig, national identity is permanently flagged in the day to day routine through language, symbols, sport and 
frames conveyed by institutions, media, family and works of fiction, building what he called "banal nationalism" (Billig, 1995). Studies also underline that such identities are not frozen but rather permanently redefined. As stated by Brubaker and Cooper, national identities appear as categories of practice "used by political entrepreneurs (...) to persuade certain people that they are (for certain purposes) "identical" to one another and at the same time different from others, and to organize and justify collective action along certain lines." (Brubaker \& Cooper, 2000, p.4-5) ${ }^{1}$. Within this framework, French nation building has been considered as an "iconic case" (Duchesne, 2016, p.487) and therefore much scrutinized: from Eugen Weber's work on the role of school and army in the nationalisation process of French peasants at the turn of the nineteenth century (Weber, 1976), through Renan's definition of the nation as a daily plebiscite (Renan 1988 [1882]), to work of historians such as Braudel (1986) and Nora (1986) on French nation-building.

National identity is not only a category of practice used by political entrepreneurs, but it is also used by citizens when asked questions such as "Who are you?","Who are we?" and "Who are they?". As claimed by Tilly, "their answers are identities (...). Identities belong to that potent set of social arrangement in which people construct shared stories about who they are, how they are connected, and what has happened to them" (Tilly, 2003, p.608). He further stated: "Without a distinctive identity called "citizen" or its equivalent, democracy cannot exist" (Tilly, 2003, p.610). It has therefore become crucial to understand how people claim to belong to a nation, which stories they tell about who they are, in order to understand polities, particularly at a time when these national identities seem to be challenged both by more multicultural societies and by calls at the regional and supranational levels to re-examine territorial identity questions.

In the French case, the first attempt to grasp empirically "What is it to be French?" was Michelat and Thomas's book on "Dimensions of nationalism" (Michelat \& Thomas, 
1966). Using a quantitative survey based on 223 interviews with French students, they distinguished three attitudinal dimensions: attitudes towards the French nation; feelings of belonging; superiority and attachment to sovereignty, which they called ideological nationalism. While the first dimension was found to strengthen nationalism on the left wing of the political spectrum, all three were recorded to structure nationalism on the right wing. They also noticed that being proud to be French appeared very important in the belonging dimension, not in the other two. They ended their book by calling for more encompassing and representative surveys on dimensions of nationalism.

Their call did not, however, receive much response. No such comprehensive qualitative survey as the one dedicated by Duchesne to the study of French citizenship (Duchesne, 1997) has been applied to the understanding of French everyday nationalism ${ }^{2}$. Researchers did not develop encompassing surveys on French nationalism till the years $2000^{3}$. Only a few indicators - on national pride and feeling of belonging to different territorial levels, including the national one - were included in post-election surveys ${ }^{4}$ and in the first waves of the EVS. They allowed to evidence that, from the end of the 1960s to the beginning of the 1990s, French nationalism, as measured by different indicators, declined in France, as in many other European countries (Dogan, 1994; Mayer, 1996). This decline, at a time when political conflicts and ideological debates became global, appeared to contribute to the fall of traditional sources of group belonging. However, contrary to expectations (Dogan, 1994), nationalism did not continue to decline from the beginning of the 1990s onwards (Duchesne \& Lavabre, 2017). On the contrary, analyses of EVS data from 1981 to 2009 showed, for example, an increase of those who claimed to be proud to be French in all social groups (Belot \& Cautrès, 2010).

Measuring national pride doesn't, however, say much about what it is to be French. Based on studies examining lay national claims in other countries, we can assume that more 
than one version of national representation influences and structures French people's relationship to their nation. Traditionally, at least two forms of nationalism are observed, ethnic and civic $^{5}$. Going back to the source of such distinction in Meinecke and Kohl in the first half of the twentieth century, Brubaker states that "civic nationalism" is "characterized as liberal, voluntarist, universalist and inclusive", "ethnic nationalism" "glossed as illiberal, ascriptive, particularist, and exclusive" (Brubaker, 1999, p.56). He, however, denounced this distinction as a "Manichean myth" due both to analytical and normative ambiguities yet acknowledging it addressed important issues. Using an exploratory factor analysis on all variables included in the ISSP 1995 dataset assessing the criteria for being "truly" a member of a particular nation, Jones and Smith reaffirmed the robustness of such distinction at the level of contemporary individual consciousness, as "ascriptive/objectivist criteria relating to birth, religion and residence can be distinguished from civic/voluntarist criteria relating to subjective feelings of membership and belief in core institutions" (Jones \& Smith, 2001, p.45)

Other studies, however, challenge this dual representation of national feeling of belonging. Using the same ISSP 1995 dataset and focusing on three countries, Germany, Sweden and Australia, Hjerm distinguished four models of national sense of belonging: civic, ethnic, pluralist (those for whom neither ethnic nor civic attributes are salient) and multiple (those for whom both ethnic and civic attributes are salient) (Hjerm, 1998a). Studying Americans' everyday nationalism and implementing a latent class analysis on quite a large number of variables - from seven items which capture what is important to be a "true" American, to pride and belief in American superiority - Bonitowski and DiMaggio also found four classes which refer to different types of nationalisms: the ardent American who scored highest on every dimension of nationalism, the disengaged from the nation, the restrictive nationalists, "who expressed only moderate levels of national pride but defined being "truly American" in particularly exclusionary ways" and the creedal nationalists "who expressed 
high levels of national pride alongside a reluctance to qualify "truly American" with many strong conditions" (Bonitowski \& DiMaggio, 2016, p.961). Observing "the robustness of the four types of American nationalism and their connection to policy preferences" (p.972), they concluded by underlining the importance of this typology when trying to make sense of a certain number of recent events in American politics, none the least D. Trump's election as American president.

As in the American case, disentangling what French people mean when expressing their national feeling of belonging might be useful in order to better understand current changes in French politics. In the literature on national identity, France is often compared either to the British or to the German models of national identity. French Universalist model of the nation is opposed to multicultural British model (Favell, 1998 ; Schiffauer et al., 2006). At the same time, French assimilationist model is presented as contrasting the German ethnocultural and differentialist model (Brubaker, 1992). Following these distinctions we should assume French people to claim their national feeling of belonging on more civic than ethnic terms.

Yet, since the beginning of the 1980s, the National Front party proposes an ethnocultural frame of French national identity. Moreover, from the 1980 onwards, most French political leaders have developed, in the context of globalisation, a discourse on the fundamental need to protect the diversity of cultures which challenges the Universalist representation of the French nation (Laborde, 2001). Thus, these changes might have affect how French people think about themselves and what constitutes the French Nation and might have built up on strains in the French model. Qualitative studies acknowledge a tension in the assimilationist and Universalist model. Looking at how national identity is thought in French schools, studying school books and observing classrooms, Bozec noticed a contradictory orientation in school discourses, from the French third republic to nowadays. While the 
French nation is always described as Universalist, bringing Human rights to the world, its main national figures are ethnically anchored which blurs the Universalist message and bring teachers to think about their pupils' origins and religious diversity only as a problem (Bozec, $2010)^{6}$. Studying nationalism as a socialisation process through interviews and observations with French and English children Throssel concluded that in France a tension exists between valuing difference and saying it is important to be the same. Acknowledging foreign origin thus appears to detract rather than add to French national feeling of belonging (Throssel, 2015). Therefore, while assuming French people to claim their national feeling of belonging more on civic rather than ethnic terms, we expect variations in French nationalism, which might reflect these fundamental tensions observed in qualitative data.

From a contested to a consensual nationalism? Changes in French national pride (19812018)

Disentangling nationalism appears much more crucial when nationalism is shared by a vast majority of the French people than by a tiny minority. Measuring French people's national identity claims therefore constitutes a prerequisite to the study of varieties of French nationalism ${ }^{7}$. While the International Social Survey Programme (ISSP) offers the most encompassing survey on identities and citizenship, we have decided to use EVS data as it offers to go back as far as 1981 and it allows the capture of the link between varieties of French citizens' nationalism and preferences towards other values and a few policies. Yet, only one question on how people relate to their national identity was asked from the first EVS wave in 1981 to the last one in 2018. This question measures national pride. In the literature, national pride is acknowledged as "an important component of national identity (...). National pride is the positive affect that the public feels towards their country as a result of their 
national identity" (Smith, 2009, p.197). Therefore, we can consider national pride as a rough measurement of nationalism.

A few studies have already been looking at people's claims regarding their pride in being French using the EVS from 1981 onwards (Belot \& Cautres, 2010 ; Belot, 2019). They observe that while French national pride already appeared quite consensual at the beginning of the 1980 s, it is even more consensual today with more than half $(53 \%)$ of the French population claiming to be very proud (against 35\% in 1981, see graph 1). This result is striking, particularly when compared to the decline of national pride during most of that same period in the British case (Tilley \& Heath, 2007).

\section{Graph 1: Evolution of French pride (1981-2018)}

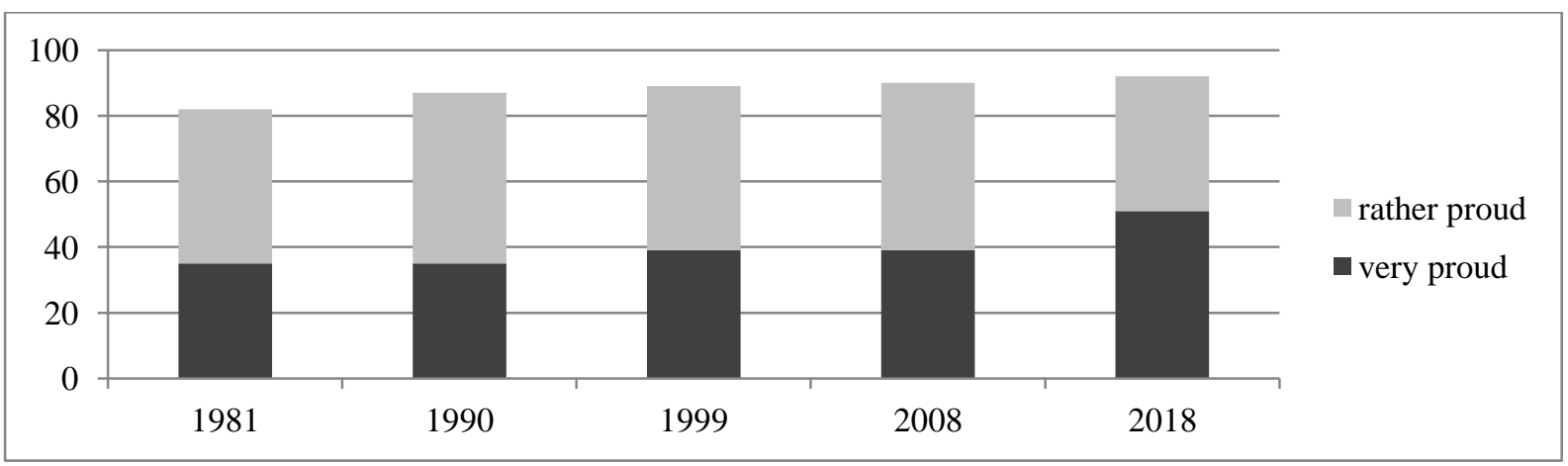

Nb. Without "don't know" and missing data. Only 1\% declared they didn't know in 2018 . They were $7 \%$ in 1981. All interviews with non-French nationals were excluded from the analyses.

More precisely, in 1981 claiming to be "proud to be French" was widespread (82\%) but views on this issue were nonetheless divided across social groups. Those who acknowledge the more conservative views on political moral and religious ground, the oldest, Catholics, people closed to the far right, were more proud than average. Conversely, those on the left, more permissive on moral values and atheistic were much less proud than average (Belot \& Cautres, 2010). National feeling of belonging appeared specifically to be tarnished by the methods of the French army in Algeria and the police in mainland France during the 
Algerian War of Independence (Belot, 2013). Looking at national pride in 2018, none of these distinctions are observed. Compared to what it was in 1981, claiming to be proud to be French is now common for all age, social and political groups. Even though a few differences between groups remain - the younger and radical left-wingers are still less proud than on average - these differences are much weaker than they were in 1981 and can only be observed looking at those who claim to be "very proud" (Belot, 2019). Looking at the level and strength of national pride, we can thus claim that nationalism currently constitutes an element which brings together the French citizenry. However, for this claim to be fully supported, we need to make sure French people all refer to the same representation of what it is to be French.

\section{Towards a typology of the varieties of French nationalism}

In the EVS 2018 questionnaire, a battery of five questions was included in order to tap respondent's normative conception of membership in the national community. People were asked about what they considered as the attributes defining "true" nationals (such as place of birth, ancestry, language, culture and respect of laws and institutions $)^{8}$. Scholars usually used these items in order to distinguish between civic and ethnic conceptions of national identity. Questions on birth, ancestry, language and culture are known to measure ethnic or rather ascribed identity whereas question on laws and institutions are meant to measure civic identity (Rusciano, 2003). Yet authors have acknowledged these items are not exactly well-suited to capturing such a distinction (Wright, Citrin and Wand, 2012). Looking at the 2018 EVS results, a gradation can be observed between the items ${ }^{9}$ (see table 1). Between a fifth and a quarter of French people consider the items relative to ancestry, birth and length of residence as very important, half of them consider sharing culture as very important, two thirds believe speaking French is very important and four fifths that laws and institutions are very important 
to be truly French. Yet this is not to say that those who believe that ancestry and birth are very important also consider institutions and laws as very important, the general picture is a bit more complicated $^{10}$.

Table 1: What is important for being truly French (EVS 2018, row \%)

\begin{tabular}{|l|c|c|c|c|c|}
\hline & $\begin{array}{c}\text { Very } \\
\text { important }\end{array}$ & $\begin{array}{c}\text { Rather } \\
\text { important }\end{array}$ & Not important & $\begin{array}{c}\text { Not important } \\
\text { at all }\end{array}$ & Sample \\
\hline Have French ancestry & 18.5 & 23.5 & 37 & 21 & 2411 \\
\hline Be born in France & 24.5 & 25 & 31.5 & 19 & 2415 \\
\hline Share French culture & 50 & 41 & 8 & 1 & 2414 \\
\hline Be able to speak French & 65 & 31 & 3 & 1 & 2429 \\
\hline $\begin{array}{l}\text { Respect French law and } \\
\text { political institutions }\end{array}$ & 79.5 & 18 & 1.5 & 1 & 2429 \\
\hline
\end{tabular}

Rather than looking for a priori distinction between ethnic and civic conceptions of what it is to be French and in order to account for distinct varieties of French nationalism, we have chosen here to use the five items included in the EVS 2018 dataset to build a typology. As these variables are not numerical variables, we used a multiple correspondence analysis (MCA) (See Leroux \& Rouanet, 2010 and appendixes 1 and 2 (section 1 and 2) for more explanations regarding the methodology). It results in creating new numerical variables - as many as the number of axes created by the analysis - which are synoptic variables summing up for each individual his positions on each of these axes. We then reinjected the coordinates of individuals of the first seven axes into an Ascending Hierarchical Clustering (AHC). AHC ended up distinguishing five clusters, those both most homogeneous within and most opposing one another (See appendixes 1 and 2 section 2 for further explanations).

The first cluster is characterised by an over-representation of the answers considering all the different items as being important to being truly French, putting aside laws and institutions. Following Rusciano's classification of these different items, the individuals 
grouped together in this cluster can be entitled "ethnic nationalists" (32\% of the sample). The second cluster is characterised by an over representation of people claiming origins and being born in France are not important to be French but sharing French culture and speaking French are quite important. It seems as if these people tend to oppose ascribed ethnic characteristics to assimilative ethnic characteristics ${ }^{11}$. They appear to consider that, among ethnic characteristics, those which might be learnt are the most important in order to be a true French. We did not find any trace of such a cluster in the literature. We propose to call the individuals gathered in this type the "cultural nationalists" (22\% of the sample). The third cluster is built on modalities pointing out everything is very important to be a "true" French person. Following Bonitowski and DiMaggio (2016), we propose to label the individuals joined in this type the "ardent nationalists" (19\% of the sample). The fourth cluster is built on modalities both rejecting origins and being born in France and considering the respect of laws and institutions as important in order to be a "true" French (18\% of the sample). As the individuals grouped in this cluster resemble the "civic nationalists" observed in the literature, we propose to use this label. Finally, the fifth cluster is characterised by modalities considering nothing is important to be truly French. The individuals gathered in this group share characteristics with the disengaged nationalists distinguished by Bonitowski and DiMaggio (2016). However, a very large majority of them declare being proud to be French (84\%), we thus prefer to call them the "relaxed nationalists" (9\% of the sample).

Our typology thus ends up distinguishing five types of nationalists, the most frequent type of French nationalism being the ethnic one, which challenge basic assumptions about what it is to be French. It is however important to underline that none of these five types can be described as strictly civic or strictly ethnic (see as well figure 3 in section 4 of appendix 2). Our analyses thus confirm that when defining what it means to be a true French person, individuals do not strictly oppose different types of criteria. In order to better understand what 
these representations of what it is to be French mean, we now propose to extend the analysis of varieties of nationalisms by looking at socio-political and attitudinal determinants of nationalism.

\section{Relationships between types of nationalism and socio-demographic characteristics}

Scholars have demonstrated that different sociological and political characteristics are associated with different types of nationalism. Age appears to play a role when trying to understand national claims, with younger people favouring "the ascribed form of national identity" and according less importance than other groups to national issues (Jones \& Smith, 2001). Our results tend to confirm these findings (see table 2). While the relaxed nationalists represent $9 \%$ of the French people, $20 \%$ of people aged 18 to 29 belong to this type. Conversely when $19 \%$ of the French people are ardent nationalists, only $11 \%$ of the young people belong to this type. The level of education has been found to be strongly associated with national claims, the higher the level of education the less ethnic the national claims (Coenders and Scheepers, 2003). More generally, observers state all individual characteristics which encourage reflexivity and open global perspectives, like cognitive skills as well as economic class position and living in a big city, sustain civic national identifications (Jones \& Smith, 2001). Our results confirm these findings as far as education and income are concerned.

We could also assume that belonging to a religion affects the type of national identification claimed by individuals. As France was long entitled "the oldest daughter of the Catholic Church", Catholicism might be linked to national identification types in which ethnic items are important, the ethnic and ardent types in our classification. Looking at our results, ethnic and ardent nationalists are indeed more numerous among the Catholics. We could also 
expect French Muslims to have negotiated a different relation between religion and national identification, as it is the case in Britain (Hopkins, 2011). Our results tend to show that civic and relaxed types of nationalism, which can be acknowledged as the less demanding types of French nationalism, are favoured by French Muslims ${ }^{12}$.

Origins are also acknowledged to influence the type of national identity displayed by individuals. Previous studies showed the strength of French national claims in the population of immigrants who adopted French nationality, with differences, however, as far as the type of national claim is concerned between those who also kept their nationality of origin and those who didn’t (Simon \& Tiberj, 2012). Meanwhile French people whose parents were foreigners and have acquired French nationality mostly believe they are not seen by others as French, even if they were born French (Jayet, 2016). More generally, observers state that people born with another nationality tend to display a rather inclusive type of national identification (Jones \& Smith, 2001). Looking at our results, origins tend to be important only for two different types of nationalism, with an over-representation of the civic type (28\% vs. $18 \%$ in the full sample) and an under-representation of the ethnic type (22\% vs. $32 \%$ in the full sample) among those from foreign origins. 
Table 2: Distribution of types of nationalism in each socio-demographic sub-sample (row \%) (EVS 2018)

\begin{tabular}{|c|c|c|c|c|c|c|}
\hline $\mathrm{V}=$ Cramer's V & Ethnic & Cultural & Ardent & Civic & Relaxed & $\begin{array}{l}\text { Sample } \\
\text { N. }\end{array}$ \\
\hline \multicolumn{7}{|l|}{$\operatorname{Sex}(V=.05)$} \\
\hline Men & 31 & 22 & 19 & 18 & 11 & 1157 \\
\hline Women & 33 & 22 & 19 & 19 & 8 & 1275 \\
\hline \multicolumn{7}{|l|}{ Age $(V=.15)$} \\
\hline $18-29$ & 29 & 20 & 11 & 20 & 20 & 421 \\
\hline $30-44$ & 28 & 24 & 13 & 24 & 12 & 526 \\
\hline $45-59$ & 33 & 22 & 19 & 19 & 7 & 645 \\
\hline $60+$ & 35 & 21 & 27 & 14 & 4 & 839 \\
\hline \multicolumn{7}{|l|}{$\begin{array}{l}\text { Education level } \\
(\mathrm{V}=.21)\end{array}$} \\
\hline Less than Bac * & 34 & 19 & 27 & 12 & 8 & 1317 \\
\hline $\mathrm{Bac}$ & 29 & 22 & 14 & 21 & 13 & 462 \\
\hline Sup Bac & 29 & 26 & 6 & 30 & 9 & 655 \\
\hline \multicolumn{7}{|l|}{ Religion $(\mathrm{V}=.15)$} \\
\hline None believer & 30 & 21 & 19 & 20 & 11 & 1439 \\
\hline Muslims & 14 & 22 & 5 & 41 & 17 & 99 \\
\hline Catholics & 36 & 23 & 23 & 14 & 5 & 797 \\
\hline \multicolumn{7}{|l|}{ Income $(\mathrm{V}=.11)$} \\
\hline 3 lower deciles & 31 & 22 & 23 & 14 & 10 & 434 \\
\hline 4 median deciles & 31 & 20 & 19 & 19 & 10 & 851 \\
\hline 3 upper deciles & 33 & 24 & 11 & 26 & 6 & 923 \\
\hline \multicolumn{7}{|l|}{ Origins $(\mathrm{V}=.16)$} \\
\hline Foreign $* *$ & 22 & 22 & 16 & 28 & 12 & 557 \\
\hline Only national & 34 & 22 & 20 & 16 & 8 & 1876 \\
\hline Average & 32 & 22 & 19 & 18 & 9 & \\
\hline
\end{tabular}

Note: Figures in bold indicate an over-representation of $4 \%$ or more, figures in italics an under-representation of $4 \%$ or more. $*$ Bac $=$ Baccalauréat, similar to A levels in Britain, diploma obtained at the end of secondary school. ** Born abroad and/or at least one parent born abroad. All relations are significant $(\mathrm{p}<.001)$ except for religion.

To sum up, the civic type is over-represented in the group of people under 44 years old, with high levels of education, high incomes as well as Muslims and people of foreign origin. The relaxed type is over-represented among young people under 29 years old and Muslims, and the cultural type is over-represented only among people with higher education. The ethnic and ardent types share a certain number of characteristics. Both are overrepresented in the older group (60 years old and above), among people with low levels of 
education, and among the Catholics. They differ, however, regarding one criterion: the ardent type is over-represented among people with low income.

\section{Relationships between types of nationalism and political characteristics}

According to the literature, as far as the political characteristics of the individuals are concerned, left-right self-positioning seems to be linked to different types of national claims. People positioning themselves on the right wing of the political spectrum tend to adhere to a more ethnic vision whereas people on the left adopt a more civic vision (Roccas et al. 2010). Our results support these findings (see table 3). The relaxed and civic types are overrepresented among the radical leftists. They respectively represent 20 and $31 \%$ of the radical leftist but only 9 and $18 \%$ of the French people. The civic and cultural types are overrepresented among leftists ( 25 and $27 \%$ vs. 18 and $22 \%$ of the full sample), the ethnic type among rightists (43\% vs. $32 \%$ of the full sample) and the ardent type among radical rightists (45\% vs. $19 \%$ of the French people). Similarly, party identification is also linked to types of nationalism. The civic nationalists are particularly over-represented among people claiming to be close to La France Insoumise, among the Greens and among La République en Marche. The ethnic and ardent types are both over-represented among Les Républicains and the ardent type specifically among the Rassemblement national.

We could assume that satisfaction with the political system, level of political interest, level of political participation as measured by voting frequency and the practice of different forms of protest participation might also affect national claims. The most satisfied and the most regular voters could enhance the role of laws and institutions in their conception of what is needed to be French as their opinions and practices unveil their tendency to agree on and to abide by institutional rules. The role of political interest and practice of protest participation 
could be more intricate as far as national claims are concerned. Looking at our results, political interest, satisfaction with the political system and levels of protest participation all play a role when describing some specific types of nationalism. This is particularly noticeable as far as the civic type is concerned, civic nationalism being overrepresented in the group of people interested in politics, satisfied with the political system and using different forms of protest participation.

In the literature, the level of strength of national claims is also said to participate in the distinction between different types of nationalism. Bonitowski and DiMaggio observed that being very proud of one's national belonging participates in the definition of the ardent nationalist type whereas it is less important for those they called the "disengaged nationalists" (Bonitowski \& DiMaggio, 2016). Looking at our results, despite the fact that national pride is very largely shared, it is less shared by relaxed nationalists and more shared by ardent nationalists.

To sum up, the relaxed type is over-represented among radical leftists, people close to La France Insoumise and the Greens, those who participate in different forms of protest, and those who are not proud to be French. The civic type is over-represented in those interested in politics, satisfied with the French political system, those participating in all kinds of protest, those belonging to the radical Left and the Left, close to La France Insoumise, the Greens and La République en Marche and not feeling proud to be French. The cultural type is overrepresented in those satisfied with the political system, the leftists, those close to the Parti Socialiste, the Greens and La République en Marche, those participating in different kinds of protest and those who are rather proud to be French. 
Table 3: Distribution of types of nationalism in each political subsample (row \%) (EVS 2018)

\begin{tabular}{|c|c|c|c|c|c|c|}
\hline $\mathrm{V}=$ Cramer's V & Ethnic & Cultural & Ardent & Civic & Relaxed & $\begin{array}{c}\text { Sample } \\
\text { N. }\end{array}$ \\
\hline \multicolumn{7}{|l|}{ Political Interest $(\mathrm{V}=.14)$} \\
\hline Interested & 31 & 22 & 14 & 24 & 8 & 971 \\
\hline Non-interested & 32 & 21 & 22 & 15 & 10 & 1459 \\
\hline \multicolumn{7}{|l|}{$\begin{array}{l}\text { Satisfaction / Political system } \\
(\mathrm{V}=.10)\end{array}$} \\
\hline Satisfied & 32 & 26 & 11 & 23 & 8 & 604 \\
\hline Neither/nor & 33 & 21 & 20 & 16 & 9 & 672 \\
\hline Dissatisfied & 31 & 20 & 23 & 17 & 10 & 1100 \\
\hline \multicolumn{7}{|l|}{ Protest participation $(\mathrm{V}=.17)$} \\
\hline 3 to 4 & 21 & 26 & 8 & 30 & 15 & 417 \\
\hline 1 to 2 & 33 & 22 & 19 & 19 & 8 & 1315 \\
\hline none & 36 & 19 & 26 & 11 & 8 & 702 \\
\hline \multicolumn{7}{|l|}{ Left-Right Scale (V=.14) } \\
\hline $\mathrm{DK} / \mathrm{NA}$ & 31 & 24 & 21 & 14 & 11 & 452 \\
\hline Radical left & 19 & 18 & 13 & 31 & 20 & 205 \\
\hline Left & 26 & 27 & 11 & 25 & 12 & 421 \\
\hline Center & 34 & 19 & 20 & 19 & 8 & 880 \\
\hline Right & 43 & 21 & 20 & 13 & 3 & 350 \\
\hline Radical right & 27 & 23 & 42 & 6 & 2 & 125 \\
\hline \multicolumn{7}{|l|}{ Partisanship (V=.19) } \\
\hline La France Insoumise & 21 & 21 & 13 & 26 & 26 & 148 \\
\hline PS (Socialist Party) & 27 & 26 & 16 & 21 & 10 & 339 \\
\hline EELV (Green) & 27 & 30 & 8 & 27 & 15 & 118 \\
\hline REM (Macron’s party) & 31 & 26 & 11 & 28 & 4 & 292 \\
\hline Les Républicains & 45 & 17 & 26 & 8 & 4 & 194 \\
\hline Le Rassemblement national & 35 & 17 & 45 & 3 & 1 & 196 \\
\hline No party & 33 & 21 & 16 & 16 & 13 & 518 \\
\hline \multicolumn{7}{|l|}{ National pride $(\mathrm{V}=.16)$} \\
\hline Not proud & 19 & 23 & 13 & 25 & 19 & 180 \\
\hline Rather proud & 33 & 25 & 12 & 19 & 11 & 998 \\
\hline Very proud & 33 & 19 & 26 & 17 & 6 & 1228 \\
\hline Average & 32 & 22 & 19 & 18 & 9 & \\
\hline
\end{tabular}

Note: Figures in bold indicate an over-representation of $4 \%$ or more, figures in italics an under-representation of $4 \%$ or more. All relations are significant $(\mathrm{p}<.001)$.

Again the ethnic and ardent types share a certain number of characteristics: they are both over-represented in those not participating in any kind of protest and in the group of people close to Les Républicains. They are also under-represented among radical leftists, leftists and people claiming not to be proud to be French. They differ, however, on other characteristics, particularly as far as political interest and satisfaction with the political system 
is concerned: the ardent type is under-represented among people interested in politics and those satisfied with the political system. They also diverge as far as left-right self-positioning and partisanship is concerned with the ethnic type being over-represented among rightists and the ardent type among radical rightists and those who identify with the National Front. Religion, political interest, satisfaction with the political system and left-right self-positioning are thus the major characteristics which help explain differences between the ethnic and the ardent nationalists. All five types tend to differentiate more on political characteristics than on socio-demographical ones.

\section{Is nationalism linked to social attitudes and policy preferences?}

Looking at varieties of nationalism we observe that each of the five types we distinguished are specific as far as socio-demographical and political characteristics are concerned. But does it matter in order to understand French politics? In other words, does disentangling varieties of French nationalism enable us to predict other attitudes more effectively than only looking at their socio-political characteristics? More specifically, as nationalism is claimed to explain attitudes towards others - particularly immigrants in the current context - and towards fellow nationals - national identity being acknowledged as a source of solidarity which favours the welfare state -, does disentangling varieties of nationalism predict attitudes towards immigrants and national solidarity? In order to account for such relationships we conducted a series of regression analyses. We use models for ordinal outcomes (see appendix 2 section 3 for details on the model used). In the text, the effects of varieties of nationalism on the choice of one category of the dependent variable compared with another are interpreted in terms of changes in the odds. Predicted probabilities are presented in appendix 2 section 3 figure 2 . 


\section{Explaining attitudes towards immigrants by varieties of nationalism}

Previous studies investigated the relationship between perception of immigrants and forms of people's attachment to the nation. Most claimed, "ethnic national identification (...) [is] negative in that [it is] associated with an increased risk of xenophobia, whereas civic national identification (...) [is] associated with decreased risk" (Hjerm, 1998b: 346 ; see also Jones \& Smith, 2001). Studying British national identification, Heath and Tilley distinguished three groups: those who believe that both civic and ethnic aspects are important, those who consider only civic aspects as important and those who claim neither civic nor ethnic aspects are important. The civic-cum-ethnic people distinguished themselves by their anti-immigrant stances, whereas the civic-only people tended to be more favourable towards multiculturalism (Heath and Tilley, 2005). Looking at Spanish national identification, Diez Medrano observed that those who share the least negative perceptions of immigrants are gathered among individuals who appear to be indifferent to who is a member of the nation, those he called the post-nationalists (Diez-Medrano, 2005).

Following this literature, we could thus expect ardent and ethnic French nationalists to be more xenophobic and relaxed French nationalists to display the least negative perception of immigrants. We could as well expect civic French nationalists to be more favourable towards multiculturalism, that is to say, less inclined towards an assimilationist perception of immigrants. We could finally expect varieties of nationalisms to affect not only attitudes but as well policy preferences towards immigrants.

Xenophobia can be defined as "a negative attitude or fear towards individuals or groups of individuals that are in some (...) sense different from oneself or the group(s) one belongs to" (Hjerm, 1998a: 463). For the purpose of this article, xenophobia is only considered as it relates to attitudes towards immigrants. In order to measure attitudes towards 
immigrants, the EVS data offer three variables which allow building an index measuring rejection of immigrants ${ }^{13}$. We consider this index as a general measure of attitudes towards immigrants. In order to measure attitude towards multiculturalism vs. assimilationist attitude, interviewees were asked to place themselves on a 10 points scale from "it is better if immigrants maintain their distinct customs and traditions" to "it is better if immigrants do not maintain their distinct customs and traditions". Finally, only one indicator of the EVS allows measuring the impact of varieties of nationalism on policy preferences towards immigrants. Interviewees were asked if they agreed or disagreed which the following statement: "When jobs are scarce, employers should give priority to French people over immigrants". We run regressions taking these three variables as dependent variables in order to evaluate the impact of varieties of nationalism towards immigration (see results in table 4). Age, gender, diploma, family income, origins, religious affiliation, position on a left-right scale and national pride are included as control variables in all models but results are not displayed for the sake of clarity $^{14}$. As the ardent nationalists represent the most exclusive type of nationalism, we chose it as the reference class to which the other classes are compared. 
Table 4: Impact of types of nationalism on attitudes and policy preferences towards immigrants with controls (EVS 2018)

\begin{tabular}{|l|c|c|c|}
\hline & $\begin{array}{c}\text { Index rejection of } \\
\text { immigrants }\end{array}$ & $\begin{array}{c}\text { Better if immigrants } \\
\text { maintain their customs } \\
\text { vs. not maintain }\end{array}$ & $\begin{array}{c}\text { When jobs are scarce, } \\
\text { employers should give } \\
\text { priority to French people } \\
\text { over immigrants }\end{array}$ \\
\hline Relaxed & $\begin{array}{c}(1=\text { very low }->4=\text { very } \\
\text { high })\end{array}$ & $\begin{array}{c}(1=\text { maintain }->6=\text { not } \\
\text { maintain })\end{array}$ & $\begin{array}{c}\text { (1=disagree strongly- } \\
>5=\text { agree strongly }\end{array}$ \\
\hline Civic & $.102 * * * / 9.8$ & $.498 * * / 2.01$ & $(.017)$ \\
\hline Cultural & $(.022)$ & $(.110)$ & $(.019)$ \\
\hline Ethnic & $.091 * * * / 10.99$ & $.701 / 1.43$ & $.100 * * * / 10.00$ \\
& $(.018)$ & $(.132)$ & $.216 * * * / 4.63$ \\
& $.250 * * / 4$ & $.868 / 1.15$ & $(.035)$ \\
\hline N. & $(.044)$ & $(.154)$ & $.443 * * * / 2.26$ \\
\hline
\end{tabular}

Note: Estimations come from a partial proportional odds model for ordinal outcomes (to overcome the violation of parallel regression assumption by some of the independent variables). All results include controls for age, gender, diploma, family income, origin, religious affiliation, position on a left-right scale, and national pride. The ardent type is the reference category. Odds ratios are followed by their reverse odds (1/odds ratios) and their standard errors in parentheses. $* \mathrm{p}<.05 ; * * \mathrm{p}<.01 ; * * * \mathrm{p}<.001$. See appendix 2 , section 3 for further information.

Reading: The odds of having a higher index of rejection of immigrants are 0.414 times smaller for the ethnic type than the ardent one, holding all variables included in the model constant. To say it otherwise (reverse odds reading) the probability to have a lower index rejection of immigrants is 2.41 times higher for the ethnic category, when compare to the ardent one, holding all other variables constant.

Looking at our results, we find significant net associations of varieties of nationalism with attitudes and a policy preference towards immigrants. All other things being equal, including left-right self-positioning, most of the associations are significant. Results appear to describe a kind of scale, with the ardent type being the least in favour of immigrants and the relaxed or the civic types the most in favour. This is particularly true when looking at the variable which taps one policy preference towards immigrants. Holding all other variables constant, the odds of considering that "when jobs are scarce priority should be given to nationals over immigrants" decreased by a factor of .443 in the ethnic nationalists' group as compared with the ardent one, of .216 in the cultural nationalists' group, .100 in the civic 
group and .077 in the relaxed group. To reframe this reading of the results, the odds of considering that when jobs are scarce priority should not be given to nationals over immigrants are 12.99 times higher for the relaxed nationalists than for the ardent nationalists, 10 times higher for the civic ones, 4.63 for the cultural ones and 2.26 times higher for the ethnic ones when compared to the ardent nationalists. Almost the same gradation is observed when measuring general attitudes towards immigrants, with the odds of not rejecting immigrants even higher for civic nationalists (10.99 times higher) than for relaxed ones (9.8 times higher) when taking ardent nationalists as the reference.

Our results on the French case tend to confirm previous results observed in other countries on the relation between varieties of nationalism and attitudes and policy preferences towards immigrants. The more demanding and ethnic the type of nationalism displayed, the more unfavourable the attitudes towards immigrants. The more civic and relaxed the type of nationalism displayed, the more favourable the attitudes towards immigrants.

As far as attitudes concerning the idea that immigrants should maintain their customs and traditions are concerned, the association with types of nationalism appears however more difficult to analyse and does not confirm previous results observed in other countries. The relation is only significant for the relaxed type. All other things being equal, the odds of considering that it is better for immigrants to maintain their customs and traditions are two times higher (2.01) for the relaxed type than for the ardent one. The results are not significant for the civic, cultural and ethnic types. As this question is a measure of the opposition between those who favour a multicultural society $v s$. those who prefer a more assimilative society, our results show this question troubles French society. Contrary to what was expected looking at previous results in other countries, belonging to the civic type in France does not inclined toward more multicultural attitudes. This is however not surprizing when remembering the results of qualitative studies which show the tension observed between 
valuing difference and saying it is important to be the same in French's feeling of belonging ${ }^{15}$. This is also in accordance with reflections which criticize liberal perceptions of civic nationalism considering that "civic nationalism can be quite illiberal in its historically dominant assimilationist drive to make all citizens alike" (Laegaard, 2007: 42). Our results thus tend to confirm these findings with quantitative data.

Therefore, as far as attitudes and policy preferences towards immigrants are concerned and all other things being equal, distinguishing types of nationalism do matter. Taking into account their association with our three dependent variables the five types of nationalism differ significantly. Considering general attitudes, types of nationalism appear to differ more on intensity, on a quasi-continuum opposing favourable vs. unfavourable attitudes towards immigrants, than on true divergences in a multi-dimensional space. However, looking at the variable relative to preference for a multicultural society vs. an assimilative society, the picture becomes more complex and invites us to investigate varieties of nationalism further.

Explaining attitudes towards solidarity and welfare policies by varieties of nationalism

As stated by Calhoun, "Debates on nationality and citizenship need to problematize not only the contrast among territorial, civic and ethnic models, and the questions of how to understand immigrants, minorities and aboriginal populations, but also the very way in which a rhetoric of nations and nationalism shapes the representation of political community" (Calhoun, 1999: 219). While re-affirming nations as political constructions, he also claims they constitute bases for political communities by fostering solidarity towards the ingroup (Calhoun, 2007). In his book On Nationality, Miller even considers nationality as "the appropriate form of solidarity for societies that are mobile - so that clan and village can no 
longer serve as the primary forms of community - and egalitarian - so that people are no longer bound together by vertical ties to overlords and dependants". According to him, nationality "provides the setting in which ideas of social justice can be pursued (...) and it helps to foster the mutual understanding and trust that makes democratic citizenship possible.” (Miller, 1995: 184-185)

Considering this relation between nation and solidarity, we could expect different types of nationalism to play a role in shaping attitudes and policy preferences towards solidarity. More precisely depending on the type of nationalism displayed, individuals might claim solidarity towards different groups and advocate welfare policies which favour a specific group depending on how they consider their national community. Our question here thus meets the literature on "who deserves welfare?" and specifically on welfare chauvinism, which can be defined as "attitudinal preference for an exclusionist welfare state that is defined by ethnic group boundaries" (Kros \& Coenders, 2019: 862) ${ }^{16}$. Following this literature, two criteria tend to explain how people think when pointing out who deserve solidarity at the national level: identity, "people who are closer to "us" are seen as more deserving", or the only ones in the case of welfare chauvinism, and reciprocity, "people who have contributed to our group before (...) or who may be expected to be able to contribute in the future" (Van Oorshot, 2006: 26).

Unfortunately EVS 2018 offers very few indicators allowing the tapping of attitudes towards ingroup solidarities and welfare policies. People were asked if they were concerned about living conditions of people with whom they shared a territorial belonging, from the neighbourhood to the world. We consider "feeling concerned about living conditions of fellow countrymen" as a measure of national solidarity. The questionnaire also contains one variable measuring attitude towards welfare policies. It gauges confidence in the social security system. While this question is the better we have in the questionnaire in order to 
grasp attitudes towards welfare policies, it doesn't exactly fit our frame analysis. A question measuring a policy preference towards social security rather than the current system would have been better. However, we consider that when acknowledging confidence in the social security system people also say something about such policy preference.

When considering these few variables, the literature on attitudes towards solidarity and welfare policies leads us to the following hypotheses: ethnic and ardent nationalists would claim to be very much concerned by fellow countrymen whereas relaxed nationalists would claim weaker national solidarity. As far as confidence in the social security system is concerned, we would expect distrust to be stronger in the most exclusive form of nationalism as foreigners can under certain conditions benefit from the French social security system. 
Table 5: Impact of types of nationalism on attitudes towards national solidarity and welfare with controls (EVS 2018)

\begin{tabular}{|c|c|c|c|}
\hline & $\begin{array}{l}\text { Not concerned about living conditions } \\
\text { Fellow countrymen }\end{array}$ & \multicolumn{2}{|c|}{$\begin{array}{l}\text { Non-confidence in the social security system } \\
\quad l=a \text { great deal }>3=\text { not much to not at all }\end{array}$} \\
\hline & $1=$ concerned $->3=$ not concerned & 1 vs 2,3 & 1,2 vs 3 \\
\hline Relaxed & $\begin{array}{c}.726 / 1.38 \\
- \\
(.144)\end{array}$ & $\begin{array}{c}.808 / 1.24 \\
- \\
(.169)\end{array}$ & $\begin{array}{c}.808 / 1.24 \\
- \\
(.169)\end{array}$ \\
\hline Civic & $\begin{array}{c}.524 / 1.9 \\
* * * \\
(0.93)\end{array}$ & $\begin{array}{c}.629 / 1.59 \\
* \\
(.117)\end{array}$ & $\begin{array}{c}.629 / 1.59 \\
* \\
(.117)\end{array}$ \\
\hline Cultural & $\begin{array}{c}.774 / 1.29 \\
- \\
(.125)\end{array}$ & $\begin{array}{c}.716 / 1.4 \\
* \\
(.113)\end{array}$ & $\begin{array}{c}.716 / 1.4 \\
* \\
(.113)\end{array}$ \\
\hline Ethnic & $\begin{array}{c}.834 / 1.2 \\
- \\
(.122)\end{array}$ & $\begin{array}{c}1.316 / 0.76 \\
- \\
(.240)\end{array}$ & $\begin{array}{c}.722 / 1.38 \\
* \\
(.121)\end{array}$ \\
\hline $\mathrm{N}$ & 2075 & \multicolumn{2}{|c|}{2066} \\
\hline
\end{tabular}

Note: Estimations come from a partial proportional odds model for ordinal outcomes. All results include controls for age, gender, diploma, family income, origin, religious affiliation, position on a left-right scale, and national pride. The ardent type is the reference category. Odds ratios are followed by their reverse odds (1/odds ratios) and their standard errors in parentheses. ${ }^{*} \mathrm{p}<.05 ; * * \mathrm{p}<.01 ; * * * \mathrm{p}<.001$. (See appendix 2, section 3 for further information on the models)

Reading: The odds of having a higher index of unconcerned attitudes towards fellow countrymen are 0.524 times smaller for the civic type than the ardent one, holding all variables included in the model constant. To say it otherwise (reverse odds reading) the probability to be concerned by fellow countrymen is 1.9 times higher for the civic category than the ardent one.

Looking at our results, all other things being equal, including left-right self-positioning which is known to have much effect on such attitudes, we find significant net associations of varieties of nationalism with national solidarity and social security. The relation between types of nationalism and the different dependent variables is, however, much less straightforward than was the case with attitudes towards immigrants. As far as being concerned with the living condition of fellow countrymen and women, the results are only 
significant for the civic type and do not confirm our hypothesis. Holding all other variables constant, the odds of feeling concerned by the living conditions of fellow countrymen are almost 2 times (1.9) higher for the civic nationalists than for the ardent nationalists. Ardent and ethnic nationalists are thus not more concerned by the life of their fellow countrymen than other types of nationalism.

Looking at the relation between varieties of nationalism and solidarity towards other kinds of ingroups, from the local one to humans all over the world, help to understand these results (see table 2 in appendix 2 section 4). Civic nationalists appear most concerned by all ingroups whoever they include and reversely ardent nationalists are less concerned by all ingroups. It thus seems that, through these variables, we measure first solidarity towards others, whoever they are, and second solidarity towards specific ingroups. One may observe that if those concerned with others are less numerous in the ardent and ethnic types than in the civic type - whoever these others are, from people from the neighbourhood to humans all over the world- their solidarity towards people from their neighbourhood, their region and fellow countrymen is however closer to the average than their solidarity towards Europeans or the humankind. Positive bias towards the ingroup may thus foster a kind of ingroup solidarity for individuals who adhere to the most exclusive types of nationalism and whose solidarity towards other groups - ingroups as well as outgroups - is generally low.

Regarding confidence in the social security system, the association is only significant for the civic type, the cultural type and partly the ethnic type. Holding all other variables constant, the odds of acknowledging much confidence in the social security system is 1.24 higher for the relaxed type as compared with the ardent one, 1.4 times higher for the cultural one and 1.59 times higher for the civic one. As far as the ethnic type is concerned, the relation is only significant when considering the difference between those who acknowledge confidence in the social security system "to a certain extent", and those who claim not to be 
confident, with the odds of acknowledging a certain confidence in the social security system rather than no confidence 1.38 higher for the ethnic type rather than the ardent type. To sum up, varieties of nationalism help to understand attitudes towards the social security system but only when considering the most exclusive type of nationalism.

Thus, while acknowledging the existence of an association between attitudes towards solidarity and welfare policies and varieties of nationalisms, we cannot clearly conclude from our analyses that nationalism nurtures national solidarity. These results could be due to the fact that our indicators are not the best ones we could have to measure national ingroup solidarity. It could be as well that depending on your conception of the nation, you might develop solidarity only with those you consider as true nationals. Other indicators are needed in order to test such hypotheses. Our results prove at least that further studies are needed to investigate the complexity of the relation between variety of nationalisms and attitudes towards the national ingroup and the outgroups.

\section{Conclusion}

Throughout our results, we propose to distinguish five types of French nationalism. Four of them, the relaxed, civic, ethnic and ardent types, resemble types already described in the literature on varieties of nationalisms in other countries. Our results thus add observations on the French case to this literature. The civic and ethnic types we observe are not as strictly exclusive from one another. Here our results confirm again recent results observed in other countries. The fifth type, cultural nationalism, particularly needs further investigation. What do people say when they acknowledge culture as the most important attribute in order to be a true French person? Previous studies tend mostly to consider culture as an ethnic criterion ${ }^{17}$, 
but our results instil a doubt about such classification. Culture can indeed refer to language, arts or history (Hutchinson, 1999). It can also mean a way of living reflected in day-to-day practices or forms of conviviality (Laborde, 2001). This is particularly the case in France with the word culture being "notoriously ambiguous and polysemic" (Laborde, 2001: 724). As cultural nationalism appears to be shared by $22 \%$ of the French, understanding what people mean when they claim culture is very important in order to be a true French person might be worth the task.

Our study shows also that disentangling varieties of nationalism indeed do matter in order to understand French politics. Depending on the type of nationalism they endorse, French citizens do have different attitudes towards immigrants, solidarity and welfare, even when education, age and political orientation are controlled for. Our results specifically make clear that, contrary to what is mostly claimed in the literature on varieties of nationalism, civic nationalists are not in France more inclined towards multiculturalism. It confirms this question troubles the French society.

As stated above, national identity claims overwhelm French political discourses. When the National Front could once consider itself as the owner of such an issue, other political forces largely invested this issue. However, not understanding precisely what people say when they claim to be French, political elites are mostly playing with fire. Further researches are needed in order to fully understand varieties of nationalism and their implications for French political life, both qualitative - looking at day-to-day practices of everyday nationalism and dimensions of national identification - and quantitative, studying changes in varieties of nationalism. 
Acknowledgements: I would like to thank French Politics' reviewers as well as Pierre Bréchon, Bruno Cautrès, and Frédéric Gonthier for their very useful comments. Many thanks as well to Sandrine Astor, who has been of invaluable methodological help when analysing the data and writing this article. At each step, she worked by my side to face all the methodological difficulties I encountered. This article owes her a lot! All errors remain of course mine.

\section{References}

Alesina, A., Baqir, R., and Easterly W. (1999) Public Goods and Ethnic Divisions. The Quarterly Journal of Economics 114(4): 1243-1284.

Anderson B. (1983) Imagined Communities. Reflections on the Origins and Spread of Nationalism. London: Verso.

Andrieu, C., Tartakowsky, D. and Lavabre, M.-C. (eds.) (2006) Politiques du passé. Usages politiques du passé dans la France contemporaine. Aix-en-Provence: Presses universitaires de Provence.

Banting, K., Kymlicka, W. (2003) Do multiculturalism policies erode the welfare state? LIS Working Paper Series 366, Luxembourg Income Study (LIS), Luxembourg.

Barrère, A., Martuccelli, D. (1998) La citoyenneté à l'école : vers la définition d'une problématique sociologique. Revue Française de Sociologie 39(4): 651-671.

Belot, C., Cautrès, B. (2010) Etre Français. Force et diversité du sentiment d'appartenance nationale. In : P. Bréchon and O. Galland (eds.) L'individualisation des valeurs. Paris : Armand Colin, pp. 197-212.

Belot, C. (2013) Backing our Men. Comprendre le soutien des Français et des Britanniques à leurs forces armées. Gouvernement et Action Publique 2 (4): 595-620. 
Belot, C. (2019) Toujours plus fiers d'être Français ! Un sentiment partagé mais différencié. In : P. Bréchon, F. Gonthier, and S. Astor (eds.) La France des valeurs. Grenoble : PUG, pp. 54-59.

Billig, M. (1995) Banal Nationalism. Londres: Sage.

Bonikowski, B., DiMaggio, P. (2016) Varieties of American Popular Nationalism. American Sociological Review 81(5): 949-980.

Bozec, G. (2010) Les héritiers de la République. Eduquer à la citoyenneté à l'école dans la France d'aujourd'hui. Paris : Thèse de l'Institut d'Etudes Politiques de Paris.

Braudel, F. (1986). L’identité de la France. Paris : Flammarion.

Brubaker, R. (1992) Citizenship and Nationhood in France and Germany. Cambridge (MA): Harvard University Press.

Brubaker, R. (1999) The Manichean Myth: Rethinking the Distinction Between "Civic" and "Ethnic" Nationalism. In: H. Kriesi, K. Armingeon, H. Siegrist and A. Wimmer (eds.) Nation and National Identity. The European Experience in Perspective, Zurich: Rüegger, pp. 55-71.

Brubaker, R. (2004) Ethnicity without Groups. Cambridge MA: Harvard University Press.

Brubaker, R., Cooper, F. (2000) Beyond "Identity". Theory and Society 29(1): 1-47.

Burgoon, B. (2014) Immigration, Integration and Support for Redistribution in Europe. World Politics 66(3): 365-405.

Calhoun, C. (1999) Nationalism, Political Community and the Representation of Society. Or, Why Feeling at Home is not a Substitute for Public Space. European Journal of Social Theory 2(2): 217-231.

Calhoun, C. (2007) Nationalism and Cultures of Democracy. Public Culture 19(1):151-173.

Coenders, M., Scheepers, P. (2003) The Effect of Education on Nationalism and Ethnic Exclusionism: An International Comparison. Political Psychology 24(2): 313-343. 
Dekker, H., Malova, D., and Hoogendoorn S. (2003) Nationalism and Its Explanations. Political Psychology 24(2): 345-376.

Deloye, Y. (2013) National Identity and Everyday Life. In: J. Breuilly (ed.) The Oxford Handbook of the History of Nationalism. Oxford: Oxford University Press.

Diez-Medrano, J. (2005) Nation, Citizenship and Immigration in Contemporary Spain. International Journal on Multicultural Societies 7(2): 133-156.

Dogan, M. (1994) The Decline of Nationalisms within Western Europe. Comparative Politics 26(3): 281-305.

Duchesne, S. (1997) Citoyenneté à la française. Paris: Presses de SciencesPo.

Duchesne, S. (2016) National identity in France. A blind spot. In: R. Elgie, E. Grossman and A. Mazur (eds.) Oxford Handbook of French Politics. Oxford : Oxford University Press, pp. 483-504.

Duchesne, S., Lavabre, M.-C. (2017) Pas de Chrysanthèmes pour le «sentiment national. In: O. Filleule, F. Haegel, C. Hamidi and V. Tiberj (eds) Sociologie plurielle des comportements politiques. Je vote, tu contestes, elle cherche..., Paris : Presses de Sciences-Po, pp.371-396.

Eger, M. (2010) Even in Sweden: The Effect of Immigration on Support for Welfare State Spending. European Sociological Review 26(2): 203-217.

Favell, A. (1998) Philosophies of Integration. Immigration and the Idea of Citizenship in France and Britain. Basingstoke: Palgrave.

Heath, A., Tilley, J. (2005) British National Identity and Attitudes towards Immigration. International Journal on Multicultural Societies 7(2): 119-132.

Hjerm, M. (1998a) National identity: A comparison of Sweden, Germany and Australia. Journal of Ethnic and Migration Studies 24(3): 451-469. 
Hjerm, M. (1998b) National Identities, National Pride and Xenophobia: A Comparison of Four Western Countries. Acta Sociologica 41: 335-347.

Hopkins, N. (2011) Dual Identities and Their Recognition: Minority Group Members Perspectives. Political Psychology 32(2): 251-270.

Jayet, C. (2013) Etat-nation et ordre politique européen : Quels dilemmes entre diversité, légitimité politique et solidarité. Paris : Thèse de sociologie de l'EHESS.

Jayet, C. (2016) Se sentir français et se sentir vu comme un Français. Les relations entre deux dimensions de l'appartenance nationale. Sociologie 7: 113-132.

Jones, F., Smith, P. (2001) Diversity and commonality in national identities: an exploratory analysis of cross-national patterns. Journal of Sociology 37(1): 45-63.

Hutchinson, J. (1999) Re-Interpreting Cultural Nationalism. Australian Journal of Politics and History 45(3): 392-407.

Kolleen, G. (2003) When Champagne Became French: Wine and the Making of a National Identity. Baltimore: Johns Hopkins University Press.

Kros, M., Coenders, M. (2019) Explaining Differences in Welfare Chauvinism Between and Within Individuals Over Time: the Role of Subjective and Objective Economic Risk, Economic Egalitarianism, and Ethnic Threat. European Sociological Review 35(6): 860-873.

Laborde, C. (2001) The Culture(s) of the Republic. Nationalism and Multiculturalism in French Republican Thought. Political Theory 29(5): 716-735.

Laegaard, S. (2007) Liberal nationalism and the nationalisation of liberal values. Nations and Nationalism 13(1): 37-55.

Larsen, C., A. (2011) Ethnic Heterogeneity and Public Support for Welfare: Is the American Experience Replicated in Britain, Sweden and Denmark? Scandinavian Political Studies 34(4): 332-353. 
Le Pen, M. (2017a) Remettre la France en ordre. Presidential election manifesto, first round.

Le Pen, M. (2017b) Choisir la France. Presidential election manifesto, second round.

Le Roux, B., Rouanet, H. (2010) Multiple Correspondence Analysis. London: Sage.

Macron, E. (2017) Macron président - «la France doit être une chance pour tous ». Presidential election manifesto, first round.

Martigny, V. (2008) The Importance of Culture in Civic Nations: Culture and the Republic in France. Studies in Ethnicity and Nationalism 8(3): 543-559.

Martigny, V. (2010) Le goût des nôtres : Gastronomie et sentiment national en France. Raisons Politiques 37: 39-52.

Mayer, N. (1996) La fierté d'être Français, de l'indépendance algérienne à Maastricht. L'année sociologique 46(1): 151-165.

Mayer, N. (1997) Le sentiment national en France. In: P. Birnbaum (ed.) Sociologie des Nationalismes. Paris : Presses Universitaires de France, pp.273-295.

Michelat, G., Thomas J.-P. (1966). Dimensions du nationalisme. Paris: Presses de la FNSP.

Miller, D. (1995) On Nationality. Oxford: Oxford University Press.

Nielsen, K. (1996-1997) Cultural Nationalism, neither Ethnic nor Civic. The Philosophical Forum, XXVIII (1-2): 42-52.

Nora, P. (1986) Les lieux de mémoire. II - La Nation. Paris : Gallimard.

Nora, P. (2011) Présent, Nation, Mémoire. Paris : Gallimard.

Pérès, H. (1989) Identité communale, République et communalisation. A propos des monuments aux morts des villages. Revue Française de Science Politique 39(5): 665 682.

Putnam, R., D. (2007) E Pluribus Unum: Diversity and Community in the Twenty-first Century. The 2006 Johan Skytte Prize Lecture. Scandinavian Political Studies 30(2): 137-174. 
Renan, E. 1988 [1882]. Qu'est-ce qu'une nation ?: Ernest Renan : littérature et identité nationale de 1971 à 1914. Paris : Bordas.

Roccas, S., Schwartz, S. and Amit A. (2010) Personal Values Priorities and National Identification. Political Psychology 31(3): 393-419.

Rusciano, F. L. (2003) The Construction of National Identity, A 23-Nation Study. Political Research Quarterly 56(3): 361-366.

Schiffauer, W., Baumann, G., Kastoryano, R. and Vertovec, S. (2006) Civil Enculturation: Nation-state, Schools and Ethnic Differences in Four European Countries. New York: Basingstoke.

Simon, P., Tiberj, V. (2012) Les registres de l'identité. Les immigrés et leurs descendants face à l'identité nationale. Document de travail de l'INED 176: 1-40.

Simon, P., Zappi, S. (eds) (2005) La politique républicaine de l'identité. Mouvements 38: 582.

Smith, A. (1995) Nations and Nationalism in a Global Era. Cambridge: Polity Press.

Smith, T.W. (2009) National pride in comparative perspective. In: M. Haller, R. Jowell and T. W. Smith (eds.) The International Social Survey Programme, 1984-2009. Oxon: Routledge, pp.197-221.

Thiesse, A.-M. (2010) L'histoire de France en musée. Patrimoine collectif et stratégies politiques. Raisons Politiques 37: 103-117.

Throssel, K. (2015) Child and Nation. Berne: Peter Lang.

Tilley, J., Heath, A. (2007) The decline of British national pride. The British Journal of Sociology 58(4): 661-678.

Tilly, C. (2003) Political Identities in Changing Polities. Social Research 70(2): 605-620. 
Van Oorshot, W. (2006) Making the difference in social Europe: deservingness perceptions among citizens of European welfare states. Journal of European Social Policy 16(1): $23-42$.

Weber, E. (1976) Peasants into Frenchmen: The Modernization of Rural France, 1870-1914. Standford: Standford University Press.

Weil, P. (2005) Qu'est-ce qu'un Français ? Histoire de la nationalité française depuis la Révolution. Paris: Gallimard.

Wright, M., Citrin, J., and J. Wand. (2012) Alternative Measures of American National Identity: Implications for the Civic-Ethnic Distinction. Political Psychology, 33(4): 469-482.

\section{Appendix 1}

All analyses are issued from the European Values Study 2018 French Dataset. We used post-stratification weights for the descriptive results. All results are based on an "only French citizens" sample.

In order to disentangle varieties of nationalism, our analyses are based on five items. French people were asked to position themselves on a four-point scale rating the importance for being truly French (very important, rather important, not important, not important at all): Be born in France (v189), Respect French law and political institutions (v190), Have French ancestry (v191), Be able to speak French (v192), Share French culture (v193). To distinguish the different types of nationalism, we use a Multiple Correspondence Analysis (MCA) and an Ascending Hierarchical Clustering (AHC) (See appendix 2 online for details). 


\section{Section 1: Multiple Correspondence Analysis (MCA)}

Our analysis refers to 2451 individuals. We excluded 140 individuals, who are not French citizens. As non-frequent categories (frequencies less than 5\%) participate heavily in the determination of the axes, we gathered them with other categories. We transformed v190 and v192 into binary variables ("very important" versus the other categories). v193 is recoded into 3 categories (very important, rather important, not and not at all important). "Don't know" and "no answer" are treated as passive categories (3 to 16 individuals are concerned depending on the variables). We thus run our specific MCA (Le Roux \& Rouanet, 2010) on 5 active variables and 15 active categories.

In an MCA there are as many axes as the number of active variables' categories minus one (14 for this analysis after recoding some of the included variables). Six eigenvalues are exceeding the average inertia. The modified rate (according to Benzecri) of axis 1 is equal to $68.3 \%$; adding axis 2 brings the cumulated rate to $87.9 \%$ (see appendix 2 online for further information on these 14 axes (eigenvalues, variance rates and modified rates )).

\section{Section 2: Ascending Hierarchical Clustering (AHC)}

AHC assigns each individual to one cluster. It finds the most similar pair of clusters and merges them into a single cluster. It then computes distances, i.e. similarities, between this new cluster and each of the old clusters. It ends up repeating these two steps until all individuals are clustered into a single cluster (Borgatti, 1994).

Here, the AHC is applied to a cloud of points with the variance criterion. It is run on the first seven axes provided by the MCA. Together they explain $88 \%$ of the variance of the 
whole projected cloud $(100 \%$ of the modified variance after Benzecri's correction ; see appendix 2 online for further explanations on the AHC method).

AHC describes all clustering through a dendrogram and recommends focusing the analysis on either three, five or six clusters. We have decided to focus on five clusters (see appendix 2 online for further information on how these clusters were built).

At first sight, some of the types we distinguished do not appear that different. This is both the case for the ardent and the ethnic nationalists and for the civic and cultural ones. One could argue a three-type classification would have been a better methodological choice, for clarity and parsimonious reasons. Looking at the dendrogram however, when limited to three types, the ardent nationalists compound a distinctive group, the ethnic belong to the same type as the cultural nationalists and the civic to the same type as the relaxed nationalists. This strengthens our choice to work with a five-type classification.

When interpreting a cluster, we need to know how large is the cluster and what categories are over- and underrepresented. The actives categories with the strongest over and underrepresentation for each of the five clusters are listed in table 2. With only five variables and 14 dimensions, it is not surprising that several categories are overrepresented in more than one cluster, and that single categories strongly dominate in smaller clusters (Hjellbrekke, 2019).

Table 1. Over and underrepresented categories in each cluster when running the AHC

\begin{tabular}{|c|c|c|c|c|c|c|}
\hline $\begin{array}{l}\text { Cluster } \\
\text { (size) }\end{array}$ & Underrepresented & \begin{tabular}{|l|}
$\%$ in \\
the \\
cluste \\
$\mathrm{r}$
\end{tabular} & $\begin{array}{c}\% \text { in } \\
\text { the } \\
\text { sampl } \\
\text { e }\end{array}$ & Overrepresented & \begin{tabular}{|l|}
$\%$ in \\
the \\
cluste \\
$\mathrm{r}$
\end{tabular} & $\begin{array}{l}\% \text { in the } \\
\text { sample }\end{array}$ \\
\hline \multirow{8}{*}{$\begin{array}{c}\text { Relaxed } \\
\mathrm{N}=224 \\
(9 \%)\end{array}$} & ... to share French culture: quite important & 0,0 & 40,3 & ... to share French culture: not/not at all important & 100,0 & $\overline{9,3}$ \\
\hline & ... to share French culture: very important & 0,0 & 49,6 & ... to be able to speak French: quite->not at all important & 70,3 & 34,5 \\
\hline & $\ldots$ to be able to speak French: very important & 29,7 & 65,3 & $\begin{array}{l}\text {... to respect French political institutions \& laws: quite->not at all } \\
\text { important }\end{array}$ & 50,7 & 20,5 \\
\hline & $\begin{array}{l}\text {... to respect French political institutions \& laws: very } \\
\text { important }\end{array}$ & 49,3 & 79,3 & ... to have French ancestry: not at all important & 41,7 & 20,6 \\
\hline & ... to have French ancestry: very important & 4,0 & 18,3 & ... to have been born in France $:$ not at all important & 37,5 & 19,1 \\
\hline & ... to have French ancestry: quite important & 11,0 & 23,3 & & & \\
\hline & $\ldots$ to have been born in France : very important & 12,2 & 24,1 & & & \\
\hline & ... to have been born in France : quite important & 16,0 & 24,7 & & & \\
\hline \multirow{5}{*}{$\begin{array}{c}\text { Civic+ } \\
\mathrm{N}=448 \\
(18 \%)\end{array}$} & ... to have French ancestry: quite important & 0,9 & 23,3 & $\ldots$ to have been born in France $:$ not at all important & 78,9 & 19,1 \\
\hline & ... to have French ancestry: very important & 0,7 & 18,3 & ... to have French ancestry: not at all important & 84,5 & 20,6 \\
\hline & ... to have been born in France : quite important & 3,6 & 24,7 & ... to share French culture: quite important & 63,4 & 40,3 \\
\hline & ... to have been born in France : very important & 0,9 & 24,1 & ... to be able to speak French: quite->not at all important & 47,0 & 34,5 \\
\hline & ... to have French ancestry: not important & 13,9 & 36,9 & & & \\
\hline
\end{tabular}




\begin{tabular}{|c|c|c|c|c|c|c|}
\hline & ... to share French culture: not/not at all important & 0,0 & 9,3 & & & \\
\hline & ... to have been born in France : not important & 16,0 & 31,3 & & & \\
\hline & ... to share French culture: very important & 35,1 & 49,6 & & & \\
\hline & ... to be able to speak French: very important & 53,0 & 65,3 & & & \\
\hline \multirow{9}{*}{$\begin{array}{c}\text { Cultural } \\
\mathrm{N}=526 \\
(22 \%)\end{array}$} & ... to have French ancestry: not at all important & 0,0 & 20,6 & ... to have been born in France : not important & 95,0 & 31,3 \\
\hline & 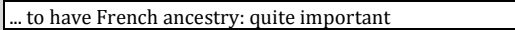 & 0,0 & 23,3 & ... to have French ancestry: not important & 99,3 & 36,9 \\
\hline & ... to have French ancestry: very important & 0,4 & 18,3 & ... to share French culture: quite important & 55,3 & 40,3 \\
\hline & ... to have been born in France : not at all important & 0,0 & 19,1 & ... to be able to speak French: quite->not at all important & 43,7 & 34,5 \\
\hline & ... to have been born in France : quite important & 0,0 & 24,7 & & & \\
\hline & ... to have been born in France : very important & 4,4 & 24,1 & & & \\
\hline & 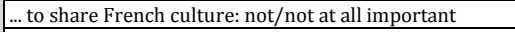 & 0,0 & 9,3 & & & \\
\hline & ... to be able to speak French: very important & 56,3 & 65,3 & & & \\
\hline & ... to share French culture: very important & 44,4 & 49,6 & & & \\
\hline \multirow{8}{*}{$\begin{array}{l}\text { Ethnic } \\
N=771 \\
(32 \%)\end{array}$} & ... to share French culture: not/not at all important & 0,0 & 9,3 & ... to have been born in France : quite important & 63,7 & 24,7 \\
\hline & ... to have French ancestry: not at all important & 1,8 & 20,6 & ... to have French ancestry: quite important & 69,9 & 23,3 \\
\hline & ... to have French ancestry: very important & 2,9 & 18,3 & ... to share French culture: quite important & 49,7 & 40,3 \\
\hline & ... to have been born in France : not at all important & 1,8 & 19,1 & ... to be able to speak French: very important & 69,0 & 65,3 \\
\hline & ... to have been born in France : not important & 13,1 & 31,3 & & & \\
\hline & ... to have French ancestry: not important & 23,5 & 36,9 & & & \\
\hline & ... to have been born in France : very important & 20,0 & 24,1 & & & \\
\hline & ... to be able to speak French: quite->not at all important & 30,5 & 34,5 & & & \\
\hline \multirow{10}{*}{$\begin{array}{l}\text { Ardent } \\
\mathrm{N}=464 \\
(19 \%)\end{array}$} & ... to be able to speak French: quite->not at all important & 1,4 & 34,5 & $\ldots$ to have been born in France : very important & 81,4 & 24,1 \\
\hline & ... to share French culture: quite important & 4,7 & 40,3 & ... to have French ancestry: very important & 88,2 & 18,3 \\
\hline & ... to have French ancestry: not important & 8,2 & 36,9 & ... to share French culture: very important & 94,3 & 49,6 \\
\hline & ... to have French ancestry: quite important & 0,0 & 23,3 & ... to be able to speak French: very important & 98,6 & 65,3 \\
\hline & ... to have been born in France : not important & 2,9 & 31,3 & ... to respect French political institutions and laws: very important & 95,9 & 79,3 \\
\hline & ... to have French ancestry: not at all important & 3,0 & 20,6 & & & \\
\hline & ... to have been born in France : not at all important & 3,1 & 19,1 & & & \\
\hline & $\begin{array}{l}\text {... to respect French political institutions and laws: quite- } \\
>\text { not at all important }\end{array}$ & 4,1 & 20,5 & & & \\
\hline & ... to share French culture: not/not at all important & 0,7 & 9,3 & & & \\
\hline & ... to have been born in France : quite important & 12,6 & 24,7 & & & \\
\hline
\end{tabular}

*categories for which the hypergeometric test is significant 


\section{Section 3: Description of variables used in the regression analyses}

For the purpose of the analyses and due to the large number of independent variables introduced in the regression models, we have transformed a certain number of variables in order to keep enough individuals in each category.

Table 2 : Description of the socio-demographic and political variables used in the logistic regressions

\begin{tabular}{|c|c|c|}
\hline Variable & Categories & Reference category \\
\hline Sexe & $\begin{array}{l}\text { Male } \\
\text { Female }\end{array}$ & Male \\
\hline Age & $\begin{array}{l}18-29 \\
20-44 \\
45-59 \\
60+\end{array}$ & $60+$ \\
\hline Last diploma obtained & $\begin{array}{l}\text { No baccalaureat } \\
\text { Baccalaureat } \\
\text { University diploma }\end{array}$ & No baccalaureat \\
\hline Religion & $\begin{array}{l}\text { Non-believers } \\
\text { Catholics } \\
\text { Muslims }\end{array}$ & Catholic \\
\hline $\begin{array}{l}\text { Income } \\
\text { Ordinal variable in } 10 \text { categories } \\
\text { recoded in } 3\end{array}$ & $\begin{array}{l}3 \text { lower deciles } \\
4 \text { median deciles } \\
3 \text { upper deciles }\end{array}$ & 3 lower deciles \\
\hline Origins $^{1}$ & $\begin{array}{l}\text { Only national origins } \\
\text { Foreign origins }\end{array}$ & Only national origins \\
\hline $\begin{array}{l}\text { Political interest } \\
4 \text { categories recoded in two (very }+ \\
\text { somewhat ; not very + not at all }\end{array}$ & $\begin{array}{l}\text { Interested } \\
\text { Not interested }\end{array}$ & Not interested \\
\hline $\begin{array}{l}\text { Satisfaction political system } \\
10 \text { points scale recoded in } 3\end{array}$ & $\begin{array}{l}\text { Not satisfied (1-4) } \\
\text { Nor satisfied, nor dissatisfied (5-6) } \\
\text { Dissatisfied (7-10) }\end{array}$ & Dissatisfied \\
\hline Protest participation $^{1}$ & $\begin{array}{l}\text { None } \\
1 \text { to } 2 \text { acts of protest participation } \\
2 \text { to } 4 \text { acts of protest participation }\end{array}$ & None \\
\hline $\begin{array}{l}\text { Political orientation }^{1} \\
10 \text { points scale recoded in } 5\end{array}$ & $\begin{array}{l}\text { radical left }(0-1) \\
\text { moderate left }(3-4) \\
\text { centre }(5) \\
\text { moderate right }(6-8) \\
\text { radical right }(9-10) \\
\text { DK }\end{array}$ & Radical right \\
\hline Partisanship $^{T}$ & $\begin{array}{l}\text { La France Insoumise } \\
\text { PS (Socialist Party) } \\
\text { EELV (Green) } \\
\text { REM (Macron's party) } \\
\text { Les Républicains } \\
\text { Le Rassemblement national } \\
\text { No party }\end{array}$ & Rassemblement national \\
\hline $\begin{array}{l}\text { National Pride } \\
4 \text { categories recoded in } 3 \text { (not very }\end{array}$ & $\begin{array}{l}\text { Very proud } \\
\text { Proud }\end{array}$ & Very proud \\
\hline
\end{tabular}


Table 3 : Description of the dependent variables used in the regressions

\begin{tabular}{|c|c|c|}
\hline Variable & EVS Variables & Recoded ategories \\
\hline $\begin{array}{l}\text { General attitudes } \\
\text { towards Immigration }\end{array}$ & $\begin{array}{l}\text { Index based on three variables which asked people to } \\
\text { place themselves on a } 10 \text { points scale: From } \\
\text { "Immigrants take jobs away from nationality" to } \\
\text { "immigrants do not take jobs away from nationality"; } \\
\text { from "immigrants make crime problems worse" to } \\
\text { "immigrants do not make crime problems worse"; and } \\
\text { from "immigrants are a strain on a country's welfare } \\
\text { system" to "immigrants are not a strain on a country"s } \\
\text { welfare system". We have built a variable which is a } \\
\text { sum of the score of each individual on these three } \\
\text { scales. In this new variable, individuals score from } 3 \text { to } \\
\text { 30. We have then transformed this variable into a four } \\
\text { categories variable }\end{array}$ & $\begin{array}{l}3-11 \text { strong rejection } \\
12-16 \text { weak rejection } \\
17-22 \text { no rejection } \\
23-30 \text { not rejection at all }\end{array}$ \\
\hline $\begin{array}{l}\text { Multiculturalism vs. } \\
\text { Universalism }\end{array}$ & $\begin{array}{l}10 \text { points scale recoded in } 6 \text { - from } 1: \text { It is better if } \\
\text { immigrants maintain their distinct customs and } \\
\text { traditions / to } 10: \text { it is better if immigrants do not } \\
\text { maintain their distinct customs and traditions }\end{array}$ & $\begin{array}{l}1-2 \\
3-4 \\
5 \\
6-7 \\
8-9 \\
10\end{array}$ \\
\hline $\begin{array}{l}\text { Job scarce, priority } \\
\text { French people over } \\
\text { immigrants }\end{array}$ & 5 categories recoded in 3 & $\begin{array}{l}\text { Agree } \\
\text { Neither agree nor disagree } \\
\text { Disagree }\end{array}$ \\
\hline $\begin{array}{lr}\text { Feeling } & \text { concerned } \\
\text { living } & \text { conditions } \\
\text { fellow countrymen }\end{array}$ & $\begin{array}{l}5 \text { categories recoded in } 3 \text { (very much }+ \text { concerned ; not } \\
\text { much }+ \text { not at all concerned) }\end{array}$ & $\begin{array}{l}\text { much concerned } \\
\text { to a certain extent } \\
\text { not concerned }\end{array}$ \\
\hline $\begin{array}{l}\text { Confidence in the } \\
\text { social security system }\end{array}$ & 4 categories recoded in 3 & $\begin{array}{l}\text { A great deal } \\
\text { Quite a lot } \\
\text { Not confident }\end{array}$ \\
\hline
\end{tabular}

As the parallel regression assumption was rejected for some of the predictors, we use a Generalized Ordered Logit model called partial proportional odds model where the parallel lines constraint is only relaxed for those variables where it is not justified (Long \& Freese, 2014). Results of these models are presented in table 4 and 5 of the article. If one or more categories of the independent variable do not respect statistical constraints, regression coefficients are different for each category of the dependent variable. In our analyses only a few categories of the independent variables do not abide by these conditions, which doesn't affect the coefficient for most of our dependent variables categories. The predicted probabilities of each category of the dependents variables for the 5 types of nationalism can be found in the appendix 2 (see figure 3 ). 


\section{References:}

Borgatti, S. (1994) How to Explain Hierarchical Clustering? Connections 17(2): 78-84.

Hjellbrekke, J. (2019) Multiple Correspondence Analysis for the Social Sciences. London: Routledge,

Le Roux, B. \& Rouanet, H. (2010) Multiple Correspondence Analysis. Quantitative Applications in the Social Sciences, 163, Sage.

Long, J.S., Freese, J. (2014) Regression Models for Categorical Dependent Variables Using Stata, Third Edition, Stata Press.

\section{Appendix 2 (Online)}

Our analyses aim at building a typology allowing differentiating varieties of French nationalism. Building this typology using qualitative ordinal variables necessitates a preliminary step which transforms these variables into quantitative variables. In order to achieve this transformation, we use an Ascending Hierarchical Clustering (AHC) of individuals based on their factorial coordinates. Factorial coordinates derive from a preliminary Multiple Correspondence Analysis (MCA). These analyses were achieved using the software SPAD.

\section{Section 1: Multiple correspondence Analysis (MCA)}

MCA offers to display the rows and columns of the data table geometrically (with rows representing individuals and columns the categories of the variables) in a lowdimensional space so that proximity in the space indicates similarity of categories and of 
individuals. See B. Le Roux and H. Rouanet for a very good introduction to such a method (2010).

Here, MCA is used to reorganise the data in order to build a clustering. The first step of the MCA aims at recoding the data using disjunctive coding. Each qualitative variable is divided into as many binary variables as its number of states. The full disjunctive table is integrated into a correspondence analysis which provides, for each individual, individual's factor coordinates. This new quantitative data table is then used when clustering individuals. To say it otherwise, the axes of the MCA are transformed as variables used for clustering individuals.

More homogenous clusters can be produced leaving aside the last factors of the MCA which allows to get rid of random fluctuations (Lebart et al., 2006). In practice, statisticians recommend to keep at least half of the axes and 80 to $90 \%$ of the total inertia (Nakache et al., 2004; Husson et al., 2016). 
Table 1. Eigenvalues, variance rates and modified rates, MCA $(\mathrm{N}=2451)$

\begin{tabular}{|l|c|c|c|}
\hline Axe & $\begin{array}{c}\text { Variance of axes } \\
\text { (eigenvalues) }\end{array}$ & Variance rates (\%) & Modified rates $(\%)$ \\
\hline 1 & 0,492 & 24,5 & 68,3 \\
\hline 2 & 0,330 & 16,4 & 8,0 \\
\hline 3 & 0,263 & 13,1 & 3,3 \\
\hline 4 & 0,220 & 11,0 & 0,8 \\
\hline 5 & 0,182 & 9,1 & 0,0 \\
\hline 6 & 0,147 & 7,4 & 0,0 \\
\hline 7 & 0,132 & 6,6 & 0,0 \\
\hline 8 & 0,089 & 4,4 & 0,0 \\
\hline 9 & 0,087 & 4,4 & 0,0 \\
\hline 10 & 0,059 & 2,9 & 0,0 \\
\hline 11 & 0,003 & 0,1 & 0,0 \\
\hline 12 & 0,001 & 0,1 & 0,0 \\
\hline 13 & 0,001 & 0,0 & 0,0 \\
\hline 14 & 0,000 & 0,0 & 100,0 \\
\hline Total & 2,005 & 100,0 & \\
\hline
\end{tabular}

\section{Section 2: Ascending Hierarchical Clustering (AHC)}

Here, the AHC is applied to a cloud of points with the variance criterion. It is run on the first seven axes provided by the MCA. Together they explain $88 \%$ of the variance of the whole projected cloud (100\% of the modified variance after Benzecri's correction). Each individual's factor coordinate becomes a value on a variable (the axis). The distances between these points are the Euclidian distances as measured by their factor coordinates. The objective of the analysis is to minimize the infraclass variance and to maximize the interclass variance. The aggregation index constitutes the lowest drop in interclass variance (Ward's criterion). That is to say, when joined together clusters are regrouped or merged in the way that results in the lowest drop in interclass variance (Hjellbrekke, 2019: 82)

One way to decide on how many clusters we should keep for interpretation is to inspect the clustering tree. 
We have decided to focus on five clusters. Using Ward's criterion, each cluster merged results in an increase in the infraclass-variance (to say it differently, a drop in interclass variance). On figure 2, a bar indicates the drop of inertia when moving from a $\mathrm{S}$ cluster solution to a S-1 cluster solution (Lebart et al. 2006). Figure 2 shows an obvious split, with a sharp drop between bar 4 and bar 5, suggesting a good partition in 5 clusters. Note that the percentage for the five clusters in the clustering tree do not exactly correspond to the percentage of the five types we are using in the following analyses. This is due to the fact that the software SPAD reallocates elements of a cluster into another cluster which they are closer to in order to ameliorate infraclass homogeneity through a consolidation algorithm.

Figure 1. Ward's aggregation index histogram on the last $50^{\text {th }}$ nodes

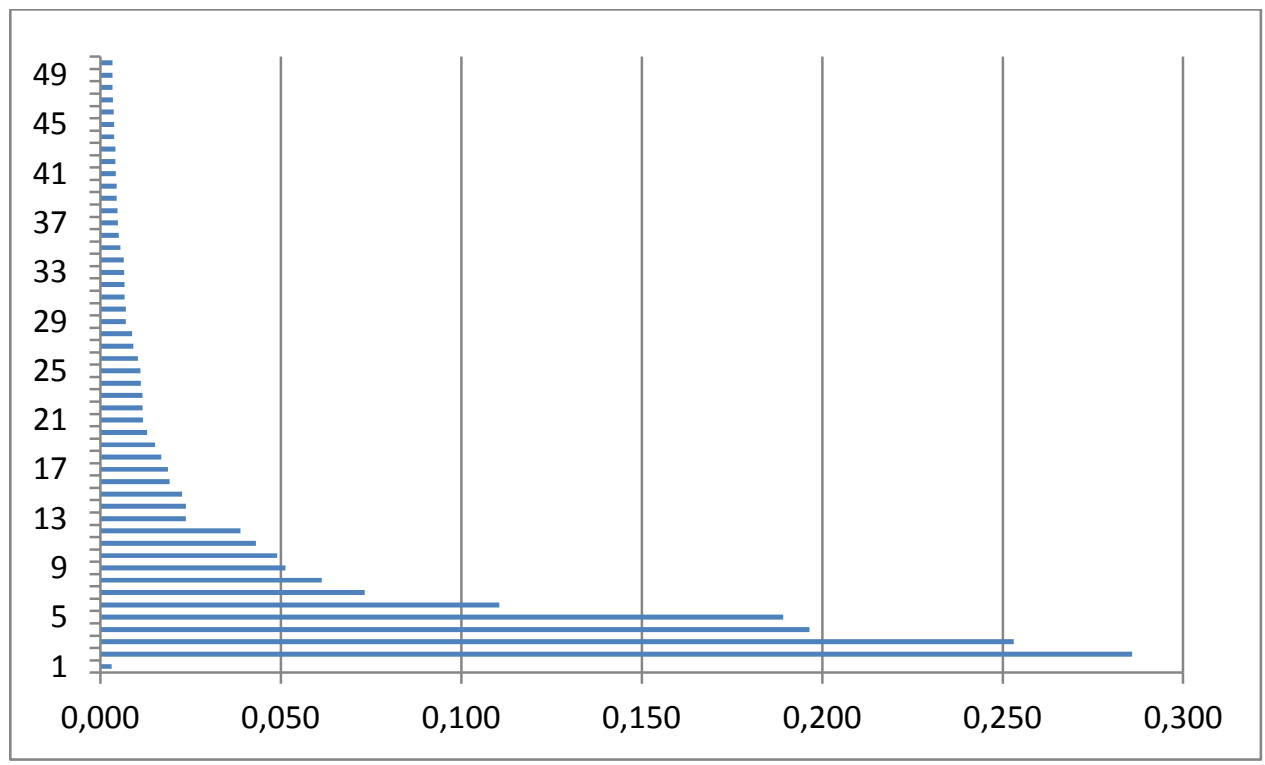

\section{Section 3: Regressions}

As the parallel regression assumption was rejected for some of the predictors, we use a Generalized Ordered Logit model called partial proportional odds model where the parallel lines constraint (proportional odds assumption) is only relaxed for those variables where it is 
not justified. Using partial proportional odds model is less restrictive than the model estimated by ordinal regression model but much more parsimonious than a non-ordinal alternative model such as multinomial logit model (Williams, 2006, Long \& Freese, 2014). In these types of models, the dependent variables are treated as ordinal. Categories are considered to have a natural ordering but the distances between the categories are unknown. The odds ratio can be interpreted in terms of changes in the odds of being in a lower outcome compared with a higher outcome when a respondent belongs to a certain type (for ex. the ethnic category) rather than the reference category (the ardent category), holding all other variables included in the models constant. For example, in the first model, three odds ratios are computed: 1/the odds for a respondent having index 1 vs $2+3+4,2$ / index $1+2$ vs $3+4,3 /$ index $1+2+3$ vs 4 . Because the parallel line assumption holds for the explaining variable (but not for all the variables included in the model), all the odds ratios are the same in each of the cumulative logistic regression.

In table 5, statistical tests reveal that the ethnic category fails to meet the proportional odds assumption for the second model (confidence in the social security system). Odds ratios differ reflecting varying effects at the different levels of the dependent variable. Belonging to the ethnic category rather than the ardent one introduces differences in both sign and magnitude across the level of confidence in the social security system (some results fail to achieve the .05 level of significance). The ethnic category is less likely than the ardent category to belong to the two lowest categories (a great deal to a certain extent) rather than the highest category (not much to not at all).

We display the probabilities of each category of the dependent variables in figure 3 . The values on the $y$ axis of each line indicate the predicted probabilities of each category computed for the 5 types of nationalism. 
In most of the cases we observe an opposition between the civic type, and to a lesser extent the relaxed type, on one side and the ethnic and ardent types on the other. Probabilities are stronger in favour of positive attitudes for the first ones and stronger in favour of negative attitudes on the other. 
Figure 2. Predicted probabilities of each category of the dependents variables for each type of nationalism

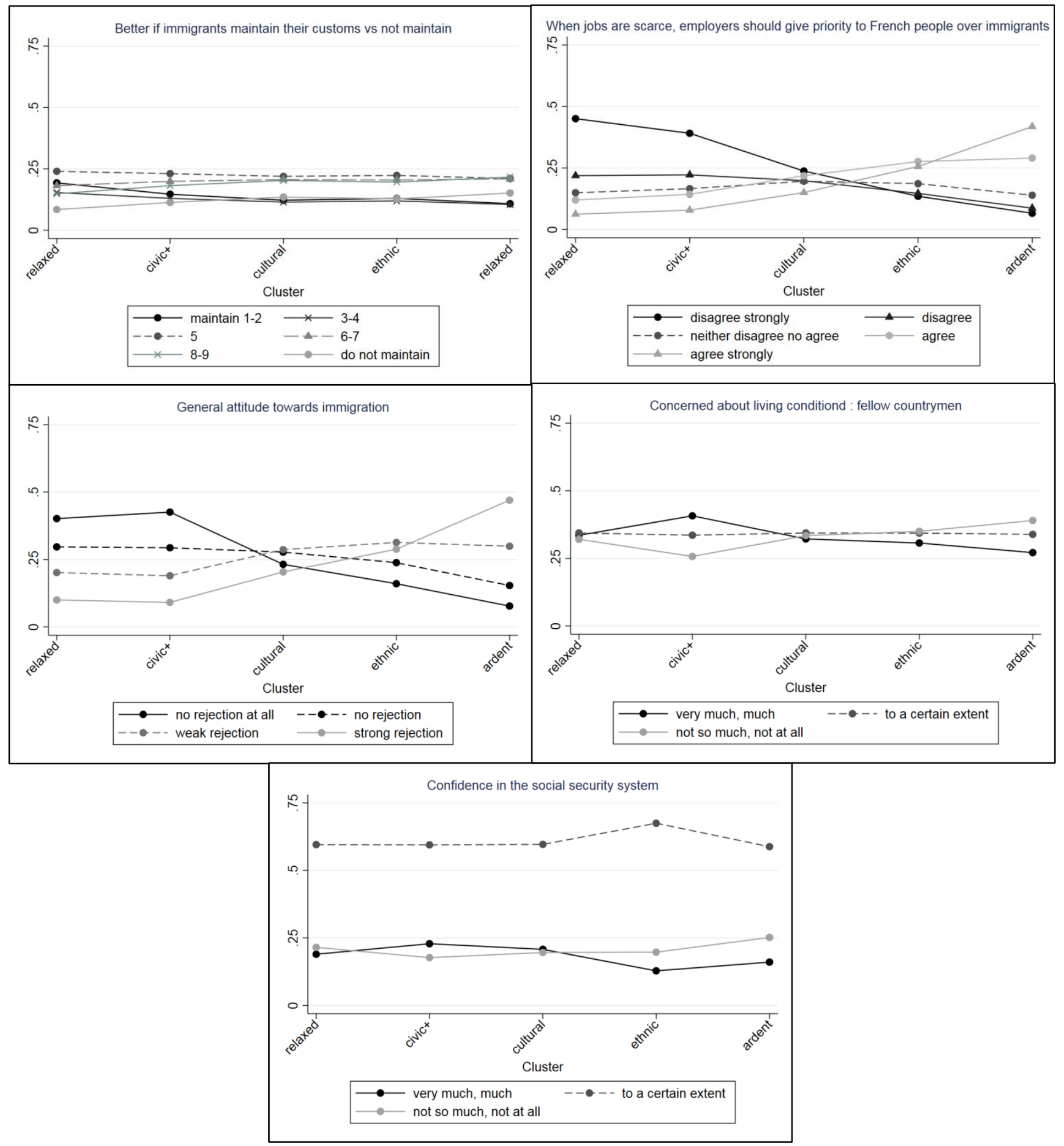

Using a partial proportional odds model other independent variables are fixed at their observed value. 


\section{Section 4: Additional information}

Figure 3: Profile of the different types of nationalism looking at what is important to be a true French
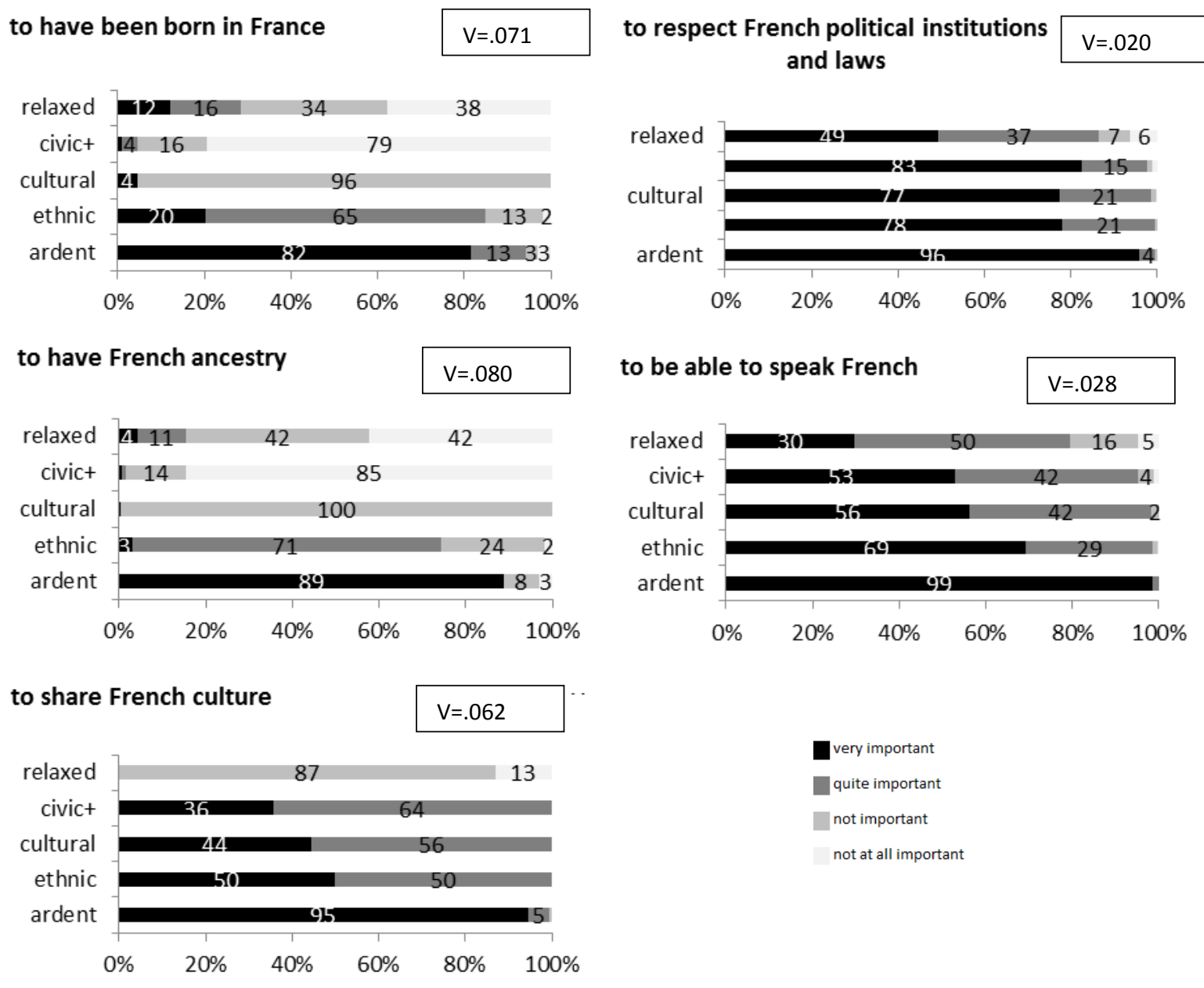
Table 2: Feeling concerned by the life of others depending from the type of nationalism (row \%) (EVS 2018)

\begin{tabular}{|c|c|c|c|c|c|}
\hline & $\begin{array}{l}\text { Concerned } \\
\text { People in your } \\
\text { neighbourhood }\end{array}$ & $\begin{array}{l}\text { Concerned } \\
\text { People of the } \\
\text { region you live } \\
\text { in }\end{array}$ & $\begin{array}{l}\text { Concerned } \\
\text { fellow } \\
\text { countrymen }\end{array}$ & $\begin{array}{l}\text { Concerned } \\
\text { Europeans }\end{array}$ & $\begin{array}{l}\text { Concerned } \\
\text { All humans all } \\
\text { over the world }\end{array}$ \\
\hline Relaxed & 69 & 61 & 69 & 58 & 69 \\
\hline Civic & 76 & 66 & 76 & 62 & 80 \\
\hline Cultural & 70 & 64 & 70 & 54 & 68 \\
\hline Ethnic & 66 & 61 & 66 & 51 & 62 \\
\hline Ardent & 60 & 50 & 55 & 34 & 45 \\
\hline Total & 68 & 61 & 67 & 52 & 64 \\
\hline
\end{tabular}




\section{References:}

Hjellbrekke, J. (2019) Multiple Correspondence Analysis for the Social Sciences. London: Routledge,

Husson, F, Lê, S, Pagès, J. (2016) Analyse de données avec R, PU Rennes; 2e ed.

Lebart, L., Piron, M. and Morineau, A. (2006) Statistique exploratoire multidimensionnelle 4ème édition. Sciences Sup, Dunod

Le Roux, B. \& Rouanet, H. (2010) Multiple Correspondence Analysis. Quantitative Applications in the Social Sciences, 163, Sage.

Long, J.S., Freese, J. (2014) Regression Models for Categorical Dependent Variables Using Stata, Third Edition, Stata Press.

Nakache, J.-P., Confais, J. (2004) Approche pragmatique de la classification, Editions Technip.

Williams, R. (2006) Generalized Ordered Logit/ Partial Proportional Odds Models for Ordinal Dependent Variables. The Stata Journal 6(1):58-82. The published article is available for free at http://www.stata-journal.com/article.html?article=st0097 


\footnotetext{
${ }^{1}$ See Deloye, 2013, for an overview on national identity and everyday life.

${ }^{2}$ See however K. Throssel's qualitative study on how French and British children learn national feeling of belonging (2015).

${ }^{3}$ The first encompassing quantitative survey on national identity, the ISSP (International Social Survey Programme) 1995 module on identity and citizenship, was not run in France. We therefore only have French ISSP dataset on identity and citizenship for 2003 and 2013.
}

${ }^{4}$ See Mayer (1997) for an analysis of the 1978, 1988 and 1995 post-electoral surveys in the study of French nationalism.

${ }^{5}$ Note that if the distinction was made to differentiate types of nations as the results of institutional and legal norms (Smith, 1995) it then became an analytical tool when trying to differentiate different national feelings of belonging.

${ }^{6}$ On this tension between the norm of Universalism and the French Republic's practices, see as well the analyses proposed in the special issue on French identity politics in Mouvements (Simon \& Zappi, 2005).

${ }^{7}$ Note that in this article, we use the term "nationalism" in order to designate all expressions through which people acknowledge or claim their belonging to a nation. There are discussions in the literature on the use of this term. Some consider it only designates its most exclusive form. Dekker et al. thus describe nationalism as characterized by "feeling a sense of belonging to a particular "nation" with a common origin, wanting to keep that "nation" as pure as possible, and desiring to establish and/or maintain a separate and independent state for that particular nation" (Dekker et al., 2003, p.347). In doing so, authors acknowledge the reality of "good" and "bad" types of national identification. On the contrary, using the term nationalism helps to get rid of such normative distinction and to comprehend the phenomenon as a whole.

${ }^{8}$ These questions, known as the "national identity module", were previously asked in ISSP 1995, 2003 and 2013 as well as in the 2008 and 2018 EVS surveys. Depending on the year and the survey, the module gathers 5 to 7 items. In the EVS dataset, there was a change in one of the items between 2008 and 2018 which doesn't allow construing a comparable index or a comparable typology using all five items. 


\footnotetext{
${ }^{9}$ This gradation parallels the gradation observed in the 2008 result.

${ }^{10}$ Some researchers consider that individual national attitudes form a cumulative hierarchy (Dekker et al., 2003, p.347). We do not find such hierarchy within the EVS items.

${ }^{11}$ This might reflect the fact that some items might be considered either as civic or ethnic depending on the context (Jones \& Smith, 2001). It could specifically be the case with culture, as it is rather a catchword which might bear different interpretations, and it may be peculiar in France, as claimed by Martigny (2008).

${ }^{12}$ These results should be taken with caution due to the small size of French Muslims in EVS sample (99).

${ }^{13}$ See appendix 1 section 3 in order to understand how this index is built.

${ }^{14}$ See the recodification of all these variables in the appendix 1 section 3.

${ }^{15}$ Obviously, this tension participates to the philosophy of French integration analysed by Favell: "to become
} French, it has to be the case that an individual's identity is not definitively determined by their racial or cultural origins, or indeed any other national identity that might clash with their new adopted French identity." (Favell, 1998: 69).

${ }^{16}$ Note that another literature links immigration and attitude towards welfare (see Alesina et al., 1999; Putnam, 2007 ; Eger, 2010 ; Larsen, 2011). This literature postulates that the more diverse ethnically a nation is, the less the support for welfare policy among its citizens (see however the discussion of such literature by Banting \& Kymlicka, 2003 ; Jayet, 2013 and Burgoon, 2014).

${ }^{17}$ See however Nielsen (1996-1997) and Brubaker (2004) on the difficulty to contain culture to an ethnic dimension. 
